\title{
TRENDS AND PROBLEMS OF INNOVATIVE ACTIVITIES DEVELOPMENT OF DOMESTIC INDUSTRIAL ENTERPRISES
}

\author{
Oksana Prodius ${ }^{1}$
}

\begin{abstract}
The aim of the article is to study the dynamics of innovations development, to identify the main problems of innovative activities development and to advance proposals for the incentive instruments formation. The main method of research is the systemic and structural approach, which makes it possible to organize the search for solving problems most effectively. Methods of comparative, functional analysis and classification are also used. The theoretical basis of the article is the conceptual provisions and scientific principles developed by domestic and foreign scientists on the innovative development of industrial enterprises, tools for their implementation. However, the problems associated with the development and implementation of an effective mechanism for applying the innovative development of industrial enterprises in the context of the need to intensify the inclusiveness of innovative processes remain unfinished. The importance and significance of these questions determined the choice of the topic of the article, setting of the purpose and objectives of the study. The article analyzes the status and dynamics of innovative activities of domestic enterprises. The main trends and problems of the enterprises' innovative development in modern conditions of limited financing and reducing the foreign investment resources are revealed. The level of using various types of innovations by industrial enterprises is investigated and the peculiarities of cost sharing for innovative activities are determined. The condition analysis of innovative activities of Ukraine's industrial enterprises is carried out, namely the ratio of innovative products sold, the ratio of enterprises engaged in innovative activities, the number of new technological processes introduction and the production development of new types of products by industrial enterprises, funding sources of innovative activities. The structural analysis of various instruments efficiency of innovations financing in the domestic market is carried out. Ukraine's innovation infrastructure should be provided with adequate resources in the context of a modern international methodology to support innovative business, which will help to minimize and close this gap. The available resources and potential should be focused on supporting research, which is one of the foundations of innovation potential, and creating an effective infrastructure that will help to transform research results into a product suitable for commercialization. Programs should be introduced to support academic payouts, start-ups, or other means of commercial use of innovative investments. The exposure-response relationships of innovative development stagnation are revealed and the ways of optimization and elimination of imbalance are provided. The recommendations for improving the innovative activities of industrial enterprises are developed.
\end{abstract}

Key words: innovative activities, industrial enterprise, innovative development, innovations, innovations management, investments.

JEL Classification: D01, F63, O33

\section{Introduction}

In modern economic conditions, one of the importantfactorsofensuringtheenterpriseseffective functioning in various sectors of the economy is the successful implementation of innovative activities. These are innovative activities that allow to ensure sustainable economic development, which requires the innovative activities intensification, increasing the innovation potential, introducing

\footnotetext{
Corresponding author:

${ }^{1}$ Odessa National Polytechnic University, Ukraine

E-mail: o.i.prodius@gmail.com

ORCID: https://orcid.org/0000-0002-0619-7567
}

the targeted strategic planning and practical use of innovations. The growing dependence of the national economy on external factors, including the negative ones, limited and expensive energy resources, the need for more rational using raw material base and labour force should serve as an incentive for using the innovations to increase the capacity to benefit from resources available in the country and imported ones, the domestic economy 
transition to the standards of economically safe production and consumption in order to ensure sustainable economic development as a whole. The abovementioned emphasizes the need to analyze the problems and trends of innovations management in a highly competitive market, the proposals development for intensifying the innovative development of domestic enterprises.

\section{Analysis of recent researches and publications}

Enterprises innovative activities are in the focus of attention of many scientists. Such foreign scientists as B. Santo, B. Twist, J. Schumpeter, M. Porter, G. Becker, Jh. Bernal, L. Venger, P. Drucker, A. Maury, N. Norman, T. Schulz, N. D. Kondratiev, R. A. Fatkhutdinov have made a major contribution to the study of the processes related to an enterprise innovative development. There also should be mentioned A. Afuan and R. Tacker's developments containing basic provisions for combining innovation and financial strategies. The instruments of ensuring the profitability of innovative developments are substantiated in T. Davila and E.Dundon's works.

The current status and problems of domestic enterprises innovative development are thoroughly covered in the works of renowned academic economists: V. Aleksandrov, A.Amoshy, L. Antoniuk, Yu. Bazhal, A. Halchynskyi, V. Heiets, S. Yerokhin, Ya. Zhalil, S. Illiashenko, M.Krupko, O.Kuzmin, O.Lapko, V.Semynozhenko, L. Fedulova, S. Filyppova, N. Chukhrai and others. Thus, L. Fedulova's articles discuss the innovative development problems of Ukraine's industrial enterprises in the areas of innovative activities, as well as the problems of optimizing the cost of innovative activities, the factors of insufficient financing of innovative activities are systematized. In their works A. Amosha, V. Zianko emphasize the positive and negative factors that affect the innovative activities of Ukraine's enterprises. A. Cherep, L. Chumak analyze the problems and priorities of innovative activities development and innovations implementation in modern conditions.

Despite the scientists' researches on enterprises innovative development, it should be noted that many issues related to solving problems and prospects of innovative development of domestic industrial enterprises in modern economic environment are still insufficiently studied and require additional studies.

\section{Economic and innovation transformations}

The domestic enterprises innovative development is obviously one of the main needs of the national economy on the way to inclusive development. It is well known that the main purpose of entrepreneurial activities is to maximize profits as the main indicator of enterprises activities. The enterprise innovative activities play one of the most important roles in this context.

Economic transformations of the 1990s were accompanied by the deterioration of the financial situation of domestic enterprises due to reduced efficiency of production capacity and high inflation rates. It led to a catastrophic decline in industrial enterprises innovative activities. Thus, in the report of 2019, Ukraine took the 47th place in the Global Innovation Index and as a result, according to all indicators, received an index of 37.4 out of 100 possible [2]. Such low rates can be explained by the fact that due to the lack of effective state support, innovative activities can be carried mainly by large enterprises, and at their own expense. High expenditures, lack of financial resources, and lack of affordable credit are key barriers to innovations in industry, and explain the low rate of expenditure spending by domestic enterprises on innovations.

Table 1 shows that over a period of 2012-2014, the innovative activities financing gradually decreased from 114,880.6 million UAH in 2012 to 7,695.9 million UAH in 2014. However, in 2015, the innovative activities financing increased to 13,813.7 million UAH, and in 2016 the financing was a record for recent years and amounted to $23,229.5$ million UAH, which is more than twice as much as in 2014. Nevertheless, in 2017 and 2018 one observed decrease in financing at the level of 9,117.5 million UAH and 12,180.1 million $\mathrm{UAH}$, respectively. As for the share of the number of innovatively active enterprises in the total number of industrial enterprises, their number over a period of 2012-2018 was approximately at the same level and amounted to approximately 16$17.5 \%$ of the total number of enterprises.

For example, in the developed world countries, such as Japan, the United States of America, China, and Germany, the share of innovative enterprises is about $70-80 \%$ of the total number of such enterprises. It also indicates that enterprises are reluctant to involve innovative technologies in their activities, and thus do not effectively use the innovation potential. Regarding the funding sources of innovative activities according to the State 
Statistics Service of Ukraine, most investments are the enterprises own funds (Table 2). On average, the enterprises own funds account for about $64 \%$ to $97 \%$ of total investments. This indicates that the main investors in innovative activities are the enterprises themselves, which over a period of strong global competition direct significant funds to the innovative technologies development.

Thus, Table 2 shows a significant decrease in innovative activities financing in Ukraine in recent years, namely in 2017, this share was approximately $0.31 \%$ of GDP, and in 2018 , it was $0.34 \%$ of total GDP. This financing is two and sometimes three times lower than in the period of 2012-2016 in Ukraine. It is also seen that the total share of investments aimed at the innovative activities development in the period of 20122016 did not exceed even about $1 \%$ of Ukraine's total GDP, and in 2017-2018 this share decreased to a critically low level over a period of 20122018, and was approximately $0.3 \%$ of Ukraine's total GDP. As for the state share of the innovative activities financing, it differed in the period of 2012-2019, but in the percentage terms from the total share of investments in innovative activities, it did not exceed $5.25 \%$ of the total amount of these investments. This indicates that the state is not the main investor in the innovative activities.

The obtained indicators show that the innovative activities in Ukraine are financed mainly at their own expense. Public financing in 2019 was only $3.9 \%$. If we consider this issue in more detail, we can conclude that in general the innovations financing at their own expense tended to increase from 2011 to 2015, afterwards there was a gradual decrease in own financing of Ukraine's industrial enterprises in their innovative activities. A significant reduction in innovations financing by foreign investors attracts attention. Thus, in 2010 this financing was $30 \%$, which was a fairly high indicator. In 2011, it was almost discontinued (0.4 \%). During 2012-2013, foreign investors began to resume the innovative activities financing, bringing their share to $13.1 \%$, after which there was another sharp cessation of innovations financing in Ukraine and in 2019 it was only $0.3 \%$. The almost complete absence of foreign investors leads to a decrease in the pace of development in scientific and technological progress and also slows down the state's economy development, which is unacceptable for our state today.
As for the funding sources of innovative activities, according to the State Statistics Service of Ukraine, most investments are the enterprises own funds. On average, enterprises own funds account for approximately $64 \%$ to $97 \%$ of the total investments. This indicates that the main investors in innovative activities are the enterprises themselves, which in the period of strong global competition direct significant funds to the innovative technologies development.

Thus, Table 2 shows a significant decrease in innovative activities financing in Ukraine in recent years, namely in 2017 this share was approximately $0.31 \%$ of GDP, and in 2018 - it was $0.34 \%$ of total GDP. This financing was twice and sometimes three times lower than over a period of 20122016 in Ukraine. It is also seen that the total share of investments aimed at the innovative activities development over a period of 2012-2016 did not exceed even about $1 \%$ of Ukraine's total GDP, and in 2017-2018 this share decreased to a critically low level over a period of 2012-2018, and amounted to approximately $0.3 \%$ of Ukraine's total GDP.

Having examined the trends in the condition of innovative activities financing in Ukraine, one can conclude that domestic innovative activities are financed at a low level, because over a period of 2012-2016 funding did not exceed even about $1 \%$, and in 2017-2018 this share did not exceed $0.3 \%$ of the total level of Ukraine's GDP. The share of innovatively active enterprises in Ukraine over a period 2012-2018 amounted to about $16-7.5 \%$ of the total number of enterprises, when, for example, in the developed world countries the indicator was about $70-80 \%$.

\section{The Innovations Implementation in Industrial Enterprises}

It should be noted that innovation processes have not gained significant scale, the number of enterprises implementing innovations decreases every year and in 2019 amounted to $13.8 \%$, which is 3-4 times less than in innovative developed economies. The research intensity of industrial production is at the level of $0.3 \%$, which is smaller than the world level. At the same time, almost a third of the funds spent on innovative activities are accounted for by the equipment purchase, while the rights acquisition to new intellectual property or $\mathrm{R} \& \mathrm{D}$ expenditures is much lower. Instead, increasing the efficiency of innovative investments amount that they receive from outside, as well as 


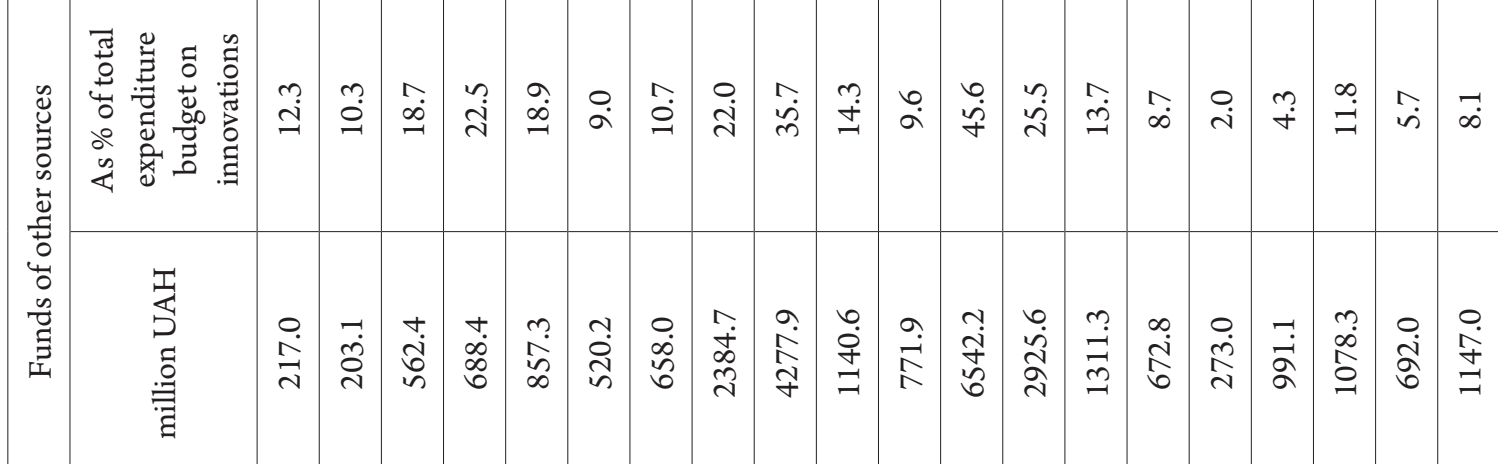

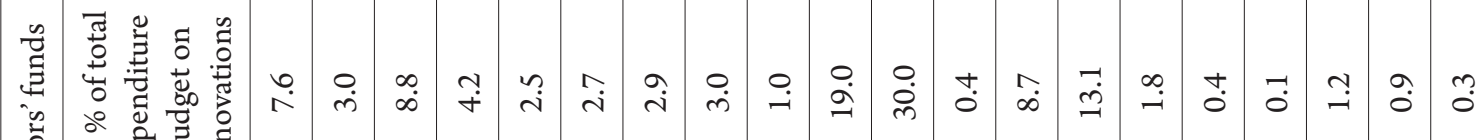

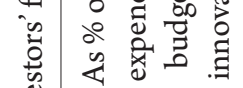

.

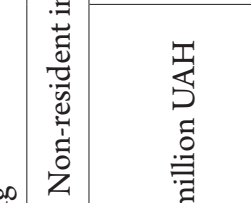

$\stackrel{\infty}{: 0}$

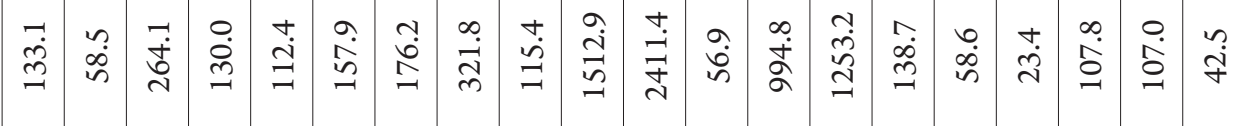

夏

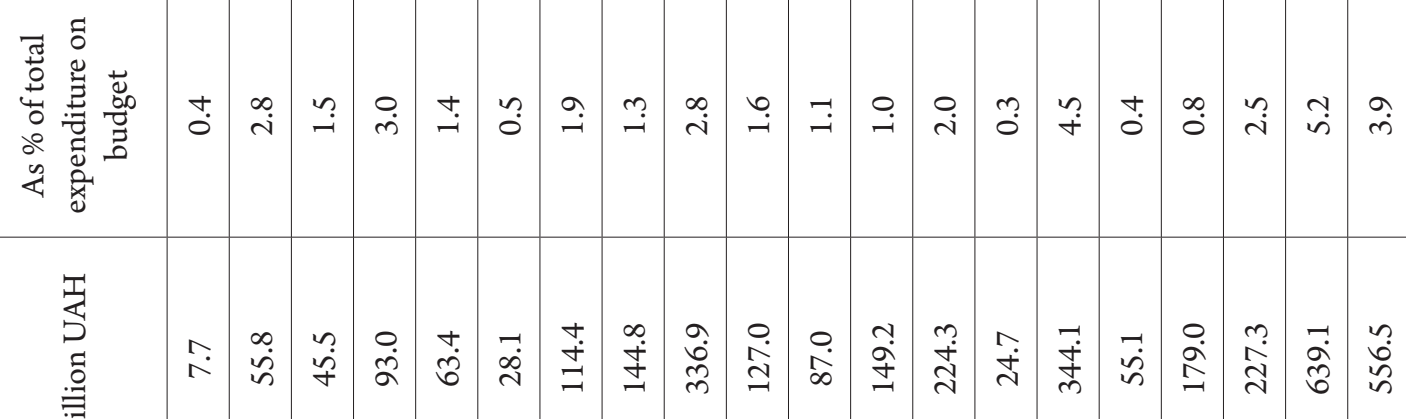

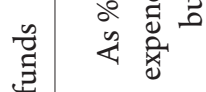

空

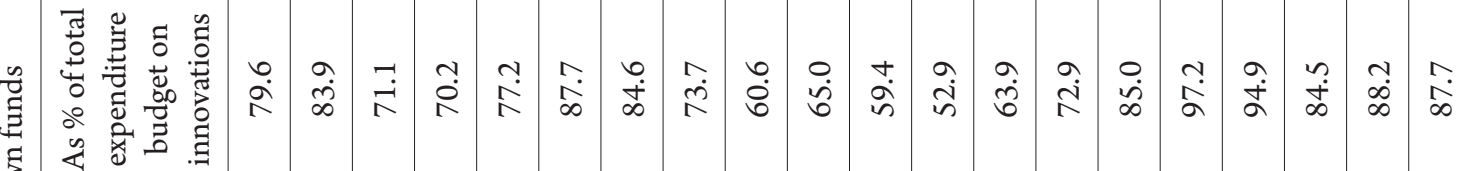
范

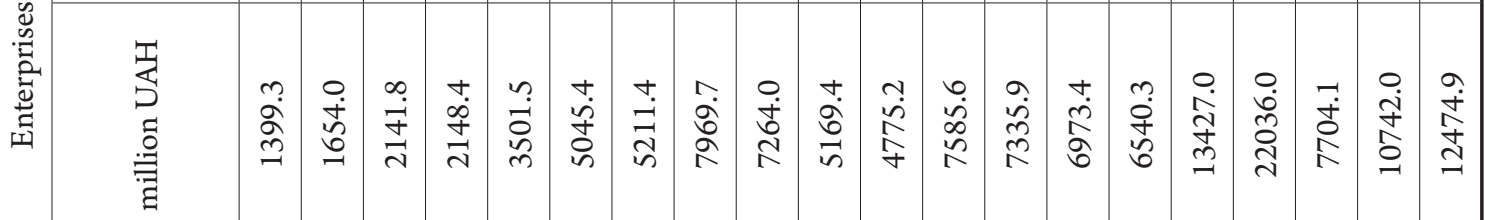

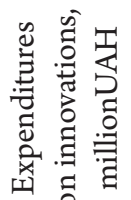

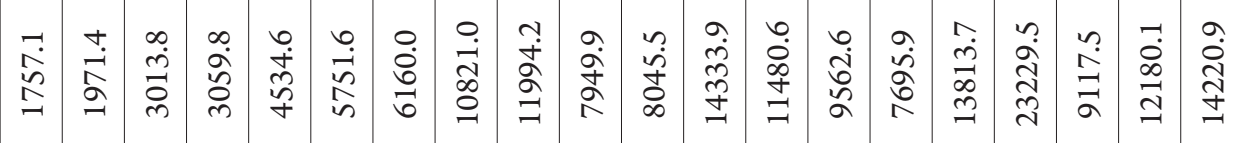

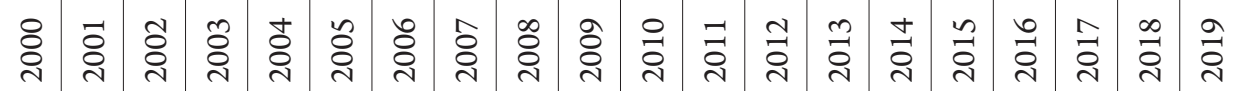


from the inner sources of the domestic high-tech production development, the dynamics of growth in the high-tech exports share, increasing the interest of foreign companies and highly qualified specialists to cooperate with Ukrainian enterprises (Table 2).

Such low innovative activities are due to both lack of funds and effective state system of stimulating the innovative activities in recent years, the beginnings of which were gradually abolished by annual amendments to the relevant budget and other laws in the last 5 years. However, the low level of research intensity of domestic production is determined not only by the lack of money or lack of incentives and benefits. The economy structure is of fundamental importance. The Ukrainian economy is dominated bylow-tech industries, which naturallybelong to the low research intensity industries: mining and fuel $0.8-1 \%$; food, light industry, agro-industry $-1.2 \%$. In general, the reproduction of the $3 \mathrm{~d}$ technological mode production dominate in Ukraine (mountain metallurgy, railway transport, multi-tonnage inorganic chemistry, etc.). Accordingly, almost 95\% of domestic products belong to the production of the 3rd and 4th technological modes. The GDP growth due to new technologies introduction in Ukraine is estimated at only $0.7-1 \%$.

\section{The problem of implemented innovations}

The dynamics of the number of enterprises that implemented innovations and their share in the total number of industrial enterprises indicate negative trends in the innovation sector, which are confirmed by the statistical data. Domestic enterprises are focused on the technological innovations introduction, and the share of nontechnological innovations is insignificant, which is explained by the lack of the enterprises attention to the development and implementation of marketing and organizational innovations. The low level of enterprises innovative activities and the declining dynamics of sold innovative products lead to increased dependence on imports of both new technologies and final science-intensive products, and to a decrease in exports of domestic innovative products. The processing industry is the leader in introducing the innovations among Ukraine's industrial enterprises: manufacturers

Table 2

The Innovations Implementation in Industrial Enterprises

\begin{tabular}{|c|c|c|c|c|c|c|}
\hline Years & $\begin{array}{l}\text { The share of } \\
\text { enterprises that } \\
\text { implemented } \\
\text { innovations, \% }\end{array}$ & $\begin{array}{l}\text { The number } \\
\text { of new } \\
\text { technological } \\
\text { processes } \\
\text { introduced into } \\
\text { production, units }\end{array}$ & $\begin{array}{l}\text { Of these, new } \\
\text { or improved } \\
\text { low-waste, } \\
\text { resource-saving } \\
\text { operational } \\
\text { procedures }\end{array}$ & $\begin{array}{l}\text { The number } \\
\text { of types of } \\
\text { innovative } \\
\text { products } \\
\text { introduced in the } \\
\text { reporting year, } \\
\text { units }\end{array}$ & $\begin{array}{l}\text { Of these, } \\
\text { new types } \\
\text { of machines, } \\
\text { equipment }\end{array}$ & $\begin{array}{l}\text { The volume } \\
\text { share of the } \\
\text { sold innovative } \\
\text { products, \% }\end{array}$ \\
\hline 2000 & 14.8 & 1403 & 430 & 15323 & 631 & 9.4 \\
\hline 2001 & 14.3 & 1421 & 469 & 19484 & 610 & 6.8 \\
\hline 2002 & 14.6 & 1142 & 430 & 22847 & 520 & 7.0 \\
\hline 2003 & 11.5 & 1482 & 606 & 7416 & 710 & 5.6 \\
\hline 2004 & 10.0 & 1727 & 645 & 3978 & 769 & 5.8 \\
\hline 2005 & 8.2 & 1808 & 690 & 3152 & 657 & 6.5 \\
\hline 2006 & 10.0 & 1145 & 424 & 2408 & 786 & 6.7 \\
\hline 2007 & 11.5 & 1419 & 634 & 2526 & 881 & 6.7 \\
\hline 2008 & 10.8 & 1647 & 680 & 2446 & 758 & 5.9 \\
\hline 2009 & 10.7 & 1893 & 753 & 2685 & 641 & 4.8 \\
\hline 2010 & 11.5 & 2043 & 479 & 2408 & 663 & 3.8 \\
\hline 2011 & 12.8 & 2510 & 517 & 3238 & 897 & 3.8 \\
\hline 2012 & 13.6 & 2188 & 554 & 3403 & 942 & 3.3 \\
\hline 2013 & 13.6 & 1576 & 502 & 3138 & 809 & 3.3 \\
\hline 2014 & 12.1 & 1743 & 447 & 3661 & 1314 & 2.5 \\
\hline 2015 & 15.2 & 1217 & 458 & 3136 & 966 & 1.4 \\
\hline 2016 & 16.6 & 3489 & 748 & 4139 & 1305 & 6.1 \\
\hline 2017 & 14.3 & 1831 & 611 & 2387 & 751 & 0.7 \\
\hline 2018 & 15.6 & 2002 & 926 & 3843 & 920 & 0.8 \\
\hline 2019 & 13.8 & 2318 & 857 & 2148 & 760 & 1.3 \\
\hline
\end{tabular}


of coke and refined products; machine building; chemical and petrochemical industry; production of food, beverages and tobacco products; metallurgy and metal processing. Insufficient financing of innovative activities hinders the industrial enterprises innovative development; the main funding source for the development and implementation of innovations in domestic industrial enterprises have been and remain their own resources, the amount of financing from public funds and foreign investment is extremely low.

The current status of innovative activities is a consequence of the lack of strategic vision and consistent state policy for the transition of Ukraine to the innovative development path, the formation of a national innovation ecosystem that would ensure its implementation and increase the innovation culture development in the country, using other mechanisms for innovative activities development. The structural elements of the national innovation ecosystem and the legal and regulatory framework in Ukraine are not integrated into a single structure, so the results of these elements are isolated and do not have a synergistic effect, which should consist in increasing the national production efficiency and enhancing their competitiveness through wide-scale implementation of the results of scientific research and scientific and technological developments.

In order to solve the problems of domestic industrial enterprises innovative development, the following elements are required: development and implementation of effective programmes to support and stimulate innovative development at the state level; providing state guarantees for projects that involve modern technological processes implementation, including low-waste, resourcesaving and waste-free; creating a favourable investment climate that will attract foreign investors from the global financial market, whose total assets are several times higher than global GDP.

\section{Conclusions}

The Ukrainian innovations infrastructure should be provided with appropriate resources in the context of an international modern methodology to support innovative business, which will help to minimize and close this gap. The available resources and potential should be focused on supporting scientific researches, which are one of the foundations of innovation potential, and creating an effective infrastructure that will help to transform research results into a product suitable for commercialization. It is necessary to introduce programmes aimed at supporting academic payments, creating a new business or other means of commercial using the innovative investments. The objectives of such strategic programmes are mission-oriented, derived from national strategies and other ambitions of the highest level. The challenges may well be economic or social, or a combination of these. A key characteristic of these programmes is that they are the top-down policy instrument: a problem is identified and then the necessary innovative solutions are developed.

The integrated management system of the enterprise innovative activities is realized by drawing up and implementating the innovative programme formulated taking into account longterm strategy of the enterprise development, its mission, technical policy and sector specificies. The task of innovative activities of this system type is to justify the enterprise long-term objectives, to implement the activities in accordance with the foreseeable opportunities and threats posed by external and internal factors, and taking into account the key competencies, competitive advantages and weaknesses of business. The strategic orientation of developing the innovation process management system leads to the large-scale introduction of new technologies, solving the problems of physical wear and aging of equipment, products, ideas and increasing the production and economic nature of an enterprise activity.

Thus, it is advisable to intensify the domestic enterprises innovative development on the basis of self-regulating innovation ecosystems that respond quickly to changes in consumer demand and are deprived of the sectoral principle of organizing the production and clear structure of processes of creating and introducing products to the market. The main parameter of the innovation ecosystems efficiency is the interaction quality between their participants, due to introducing the concept of open innovation platforms, which expands the possibilities of partnership based on scientific projects, stimulates investors' attraction and accelerates commercialization of scientific developments. At the regional level, ensuring the inclusiveness of economic development is due to the smart specialization concept, which allows to realize the unique potential of the region's economic development based on competitive advantages in accordance with the international standard. 
The national science and technology policy should ensure a breakthrough in the priority areas carried out with the participation of the state and its institutions, and overcoming the technological gap with the world leading countries. An important component of Ukraine's innovative development should be the state system of identifying and supporting the priorities implementation, from fundamental developments to participation in the manufacturing of competitive products. Decisive actions that would activate all stakeholders to accelerate scientific and technological progress and its implementation in an inclusive innovation economy to increase its efficiency and competitiveness are needed by the authorities.

\section{References:}

Pysarenko, T. V., \& Kvasha, T. K. (2019). Stan innovatsiinoi diialnosti ta diialnosti u sferi transferu tekhnolohii v Ukraini u 2018 rotsi: analitychna dovidka [The Condition of Innovative Activities and Technology Transfer Activities in Ukraine in 2018: the Analytical Report]. Kiev: UkrINTEI, p. 80.

Ofitsiinyi sait Derzhavnoi sluzhby statystyky Ukrainy [The Official Website of the State Statistics Service of Ukraine]. Available at: http://www.ukrstat.gov.ua/ (accessed: 05.05.2020).

Hechbaia, B. (2018). Hlobalni determinanty i modeli finansuvannia innovacii [Global Determinants and Models of Innovations Financing]. Mizhnarodna ekonomichna polityka, vol. 1, pp. 7-31.

Bobukh, I. M. (2018). Stratehichni oriientyry ekonomichnoho zrostannia Ukrainy: inkliuzyvnist yak kliuchovyi priorytet [Strategic Environments of Economic Growth in Ukraine: Inclusiveness as a Key Priority]. Visnyk Natsionalnoi akademii nauk Ukrainy, vol. 7, pp. 55-70.

Ukraina opustylasia v Hlobalnomu reitynhu innovatsii [Ukraine has dropped in the Global Innovations Ranking]. Available at: https://news.finance.ua/ua/news/-/453283/ukrayina-opustylasya-vglobalnomu-rejtyngu-innovatsij (accessed: 05.05.2020).

Vprovadzhennia innovatsii na promyslovykh pidpryiemstvakh [Innovations Implementation in Industrial Enterprise]. Ofitsiinyi veb-sait Derzhavnoi sluzhby statystyky Ukrainy. Available at: http://www.ukrstat.gov.ua/ (accessed: 05.05.2020).

Hryhoruk, P. M. (2018). Kharakterystyka suchasnoho stanu innovatsiinoho rozvytku Ukrainy [Characteristics of the Current Status of Innovative Development of Ukraine]. International Journal of Innovative Technologies in Economy, vol. 2(14), pp. 11-19.

Prodius, O. I. (2019). Problemy ta perspektyvy inkliuzyvnoho rozvytku v umovakh hlobalizatsii [Problems and prospects of inclusive development in the context of globalization]. Vcheni zapysky Tavriiskoho natsionalnoho universytetu imeni V. I. Vernadskogho. Seriia: Ekonomika i upravlinnia, vol. 30(69), 4, pp. $71-75$.

Zianko, V. V. (2015). Innovatsiina diialnist pidpryiemstv ta ii finansove zabezpechennia v umovakh transformatsiinykh zmin ekonomiky Ukrainy: monoghrafiia [Enterprises Innovative Activities and Its Financial Support in the Conditions of Economy Transformational Changes of Ukraine]. Vinnytsia: VNTU, $172 \mathrm{p}$.

Fedulova, L. I. (2016). Inkliuzyvni innovatsii v systemi sotsialno-ekonomichnoho rozvytku [Inclusive Innovations in the Socio-Economic Development]. Ekonomika: realii chasu, vol. 3(25), pp. 56-65.

Filyppova, S. V. (2018). Innovatsiini stratehii ta innovatsiini tekhnolohii [Innovative Strategies and Innovative Technologies]. Ekonomichnyi zhurnal Odeskoho politekhnichnoho universytetu, vol. 1(3), pp. 49-61.

Azhaman, I. A. (2019). Tendentsii stanu finansuvannia innovatsiinoii dialnosti v Ukraini [Trends in the State of Financing Innovative Activity in Ukraine]. Investytsii: praktyka ta dosvid, vol. 23, pp. 20-23. 